\title{
„Alma Mater Studiorum” - VÁLTOZÁSOK A FELSŐOKTATÁSBAN
}

\author{
CSIKA I ILDIKÓ \\ PhD-hallgató, Pécsi Tudományegyetem, Filozófiai Doktori Iskola
}

Bruno Broucker, Kurt De Wit, Jef C. Verhoeven \& Liudvika Leišytė (eds): Higher Education System Reform. An International Comparison after Twenty Years of Bologna. Leiden, Boston, 2019. Brill | Sense. ISBN: 978-90-04-40011-5 (eBook)

A Bolognai Egyetem alapítása óta Isten magasztalásától az önmegvalósításon át az igazság kereséséig hosszú volt az út az egyetemi oktatási célok fejlődésében. A technológia és a mesterséges intelligencia térhódítása, töretlen fejlődése készenléti ügyeleti helyzetbe hozza a felsőoktatást, amelynek ma már talán elsődleges célja túl a szakmai tudás átadásán, az alapvető készségek fejlesztésén, a megfelelő szemlélet kialakításán, a kritikai gondolkodás fejlesztésén, a látómező szélesítésén, a kapcsolatrendszer kialakításán -, hogy segítse a hallgatókat az élethosszig tartó tanulás elindításában, a folyton mozgásban lévő körülményekhez való alkalmazkodásban. Kiss Árpád már 1969-ben így fogalmazott: „Ma mind az elméleti, mind a gyakorlati pedagógia megtorpan amiatt, hogy a változás és a változó ember megtervezésének nincsen kész modellje..." (Kiss 1969: 8.)

A felsőoktatási rendszerekben bekövetkezett változások mérföldkövei voltak a 60-as, 70-es évek diáklázadásai. A változás a brit egyetemeken az állami irányítást hozta, illetve a Thatcher-féle kormányzás alatt az egyetemi költségvetés csökkentését, az egyetemek között a piaci verseny megszületését és a monitoringrendszer kialakítását. Egy másik mérföldkőnek tekinthető az oktatási kérdések közös platformra helyezésének gondolata Euró- pában, ami 2008-ban a négy ország által aláírt Sorbonne-i Nyilatkozatban fogalmazódott meg, mely a koordinált európai felsőoktatás reformját indította el. $\mathrm{Az}$ aláírók bíztak abban (és ennek nyomában jár annak a huszonkilenc országnak az akarata, mely egy évvel később Bolognai Nyilatkozatban öltött testet), hogy az európai kulturális identitás erősödni tud, hogy sikerül felvenni a versenyt az amerikai egyetemekkel, hogy az európai egyetemek képesek lesznek a legtehetségesebb oktatókat, kutatókat megtartani. A Nyilatkozat eredeti hat célja között szerepelt az egységes képzési szerkezet kialakítása, az alapvetően kétciklusú képzés (ill. a doktori képzést is tekintve: három ciklusú) képzés bevezetése az átjárhatóság szempontjait figyelembe véve, a kreditrendszer megalkotása, a mobilitás, az azonos feltételekkel működő minőségbiztosítási rendszerek kivitelezése, az európai nézőpontú, nemzetközivé váló felsőoktatás erősítése. $\mathrm{A} z$ évek során nem csupán a rendszerben részt vevő tagországok létszáma növekedett, de a célok is kiegészültek olyan új fogalmakkal, mint a tanulóközpontú tanulás, az élethosszig tartó tanulás vagy az Európai Felsőoktatási Térség.

A több mint 20 kutató 2019-ben megjelent munkája, mely 12 európai ország felsőoktatás-reformját vizsgálja, többek között az alábbi kérdésekre keresi a választ: 
Milyen (gazdasági, társadalmi, politikai) tényezők hatottak a reformra az egyes országokban? Hogyan oldották meg az átmenetet a korábbi gyakorlat és a tervezett célok elérése érdekében? Hol tart jelenleg a felsőoktatás az eredetileg kitűzött hat célt figyelembe véve? Melyek azok a reformintézkedések, amelyek a jelenlegi helyzethez vezettek? Milyen logika és milyen vezetési tényezők húzódnak meg a reformok hátterében?

A szerkesztők elsőként fogalmakat tisztáznak. Többek között azt, hogy mit értenek a felsőoktatási rendszer reformjain (a közigazgatási reform megfogalmazását alkalmazzák). Bár csak a felsőoktatási rendszereket világítják át egy-egy országban, ezek azonban magukba foglalnak intézményeket, döntéshozókat, vezetőket, valamint a közigazgatásnak is szerep jut az elemzésben ott, ahol hatása lehet a felsőoktatás működésére. Nem csupán a nemzeti vagy helyi szervezetek, érdekcsoportok befolyásolják a felsőoktatás formálódását, de „nemzetközi szervezetek és nemzetek felett álló struktúrák is", mint például az OECD, az UNESCO vagy az EUA (p. 8).

Belgiumot, pontosabban a Flamand régiót tulajdonképpen az első felsőoktatási reform tette szövetségi állammá. Az 1970-71-ben végrehajtott reform a korábbi ideológiai, gazdasági-társadalmi és nyelvi feszültségek miatt vált szükségszerüvé. Az 1988-89-es alkotmánymódosítás tovább erősítette a szövetségi állammá alakulás folyamatát. De Wit, Verhoeven és Broucker részletesen bemutatják a Belgiumban lezajlott változást, annak logikai vázát, a bolognai folyamathoz való csatlakozáshoz vezető utat, azokat a szervezeteket, amelyek hangot adhattak véleményüknek még a közös nyilatkozat aláírása előtt. Azóta több diákot vonz a felsőoktatás, a befejezett tanulmányok száma nőtt, a felsőoktatás nyitottá vált, a kevésbé kiváltságos családból jelentkező diákok is könnyebben bejuthatnak.

Németországban 1968 óta nem volt olyan mértékű átalakítás a felsőoktatásban, mint a bolognai folyamat hatására. A diákok tiltakoztak az iskolarendszerü felsőoktatás fejlesztése és a túlterhelt oktatási programok, valamint az alapképzés és a mesterképzés közötti átmenet ellen. Válaszul az akkori oktatási miniszter két csúcstalálkozót szervezett, amire azért is volt nagy szükség, mert európai összehasonlításban már láthatóvá váltak a német felsőoktatás gyengéi. Peksen és Zeeman szerint az összes probléma az alapképzésmesterképzés szerkezetének megvalósításával kapcsolatos döntéshozatalból eredt. A bolognai reformokat úgy kezelték, mint a sajátos német felsőoktatási problémák megoldásának kulcsát. A két kutató szerint a bolognai folyamatra igen erös hatással volt a New Public Management szemlélet (ami a költséghatékonyságot, a szolgáltatás minőségének emelkedését, mérhetőségét, az intézkedések koherenciájának és koordinációjának erősítését, valamint a szolgáltatásokhoz való egyenlő hozzáférést célozza). A jelentős változások dacára néhány eredetileg is hangsúlyos cél, mint például a lemorzsolódási arány, illetve az egy-egy szakon eltöltött időtartam csökkentése, még nem valósult meg.

Christine Teelken írja a holland felnőttképzést elemző tanulmányában: „tekintettel a bolognai folyamat által bekövetkezett drámai változásokra [az elkövetkezendő időszak kihívásaira gondolva] a kritikus álláspont elengedhetetlen az európai felsőoktatás jövője szempontjából” (p. 53). Bevezetőjében az is hangsúlyt kap, hogy a bolognai folyamathoz különböző idöpontokban csatlakozó európai országok különböző ütemben tudták végrehajtani a változtatásokat, és ez együtt járt egy rendkívül összetett kulturális és társadalmi átalakulással. Hollandia, mint általában 
a jóléti társadalmak, régóta rendelkezik kidolgozott szociális hálóval. Mindkét holland felsőoktatási szint (egyetemek és alkalmazott kutatással foglalkozó egyetemek) nagy hagyományokkal rendelkezik (1575: Leiden, 1614: Groningen, 1636: Utrecht), és hangsúlyozottan törekszik az egyenlőség megvalósítására. Az implementációhoz még a flamandoknál is gyorsabban fogtak hozzá („elöfutárnak” nevezi a szerző Hollandiát, p. 63). A legnagyobb problémát a négyéves doktori képzések okozták, amelyek egyfajta "fekete doboz"ként funkcionáltak, és a professzorok egyéni területétől függtek (p. 56). A kutatás tükrében Hollandiában, úgy tünik, a legtöbb bolognai cél megvalósult, az implementáció lezajlott, a mobilitás virágzik, a minőségbiztosítási mutatók elfogadhatóak, és a jelenlegi akkreditációs eljárás még inkább az európai dimenziót erősíti.

Finnország számos felsőoktatási reformot vezetett be az elmúlt évtizedekben. A bolognai folyamat elindítása igazi kihívás volt, hiszen korábban az alapképzést nem ismerték el önálló diplomaként, így a munkaerőpiacon nem sokat ért (igaz, a munka világába való belépéshez még ma is alapelvárás a mesterdiploma), és a két szint közötti átmenet sem volt egyértelmüen definiálva. Mindezek ellenére nagyon hamar adoptálták a bolognai célokat, és talán a legfigyelemreméltóbb az, ahogyan a törvénykezés támogatta a megvalósulásukat. A tradicionális finn felsőoktatás, ugyancsak a jóléti államok ideológiai gyökerein eredezve, az egyenlőséget hirdeti, amivel nemigen harmonizálnak a piacorientált érvek, mint versenyképesség, hatékonyság, felelősségre vonhatóság. Ennek ellenére a reformok végrehajtása meglehetősen simán ment, és ez annak is köszönhető, hogy a felsőoktatás már a bolognai reformok előtt „rendben volt”. A gazdasági indítékok igen erőteljesek voltak a finn felsőoktatási intézkedések végrehajtásában, és ez részben tükrözi azt a hihetetlen eröfeszítést is, amit Finnország megkísérelt annak érdekében, hogy a csökkenő források mellett megőrizze a jóléti társadalom hagyományos értékeit.

Dániában az 1960-as évek közepén kezdődtek a reformok, de az igazi átalakulást 1993 hozta, amikor az akkori kormány új felsőoktatási törvényt alkotott. A Bolognai Nyilatkozat aláírása a folytonosságot és a változások követését jelentette. 2000-től felnőttek számára is megnyílt a felsőoktatás az élethosszig tartó tanulást támogató felnőttképzési törvény elfogadása után. A változások hatására az intézmények megnövekedtek, és az emelkedő - bár még mindig viszonylag alacsony - felvételi mutatók miatt a 25 évvel korábban provokált félelmek (hogy túlképzés és hatalmas diplomás foglalkoztatás lesz) ismét aktivizálódtak. Palle Rasmussen felveti, hogy Dánia vajon a Bolognai Nyilatkozat nélkül is eljutott volna a jelenlegi eredményekig.

A $z$ olasz felsőoktatás reformja az állami szektor átalakításával együtt zajlott a $\mathrm{New}$ Public Management mentén. Agasisti és Dal Molin szerint a politikai és társadalmi tényezőket figyelembe véve ez volt a legmegfelelőbb paradigma az Olaszországot érintő számos feszültség kezelésére. Mint mindenütt, a felsőoktatás több funkcióval rendelkezik, egyrészt „áru”, másrészt érinti a fogyasztás, ugyanakkor az állami szerepvállalás elengedhetetlen, hiszen az egyetemek pozitív externáliái az egész közösségre hatással vannak. Ezt a folyamatot „kvázi piaci modell”-nek nevezik. Az OECD (2018) jelentése szerint a 30 év alatti diplomások száma Olaszországban az egyik legalacsonyabb (Svájcban, Németországban, Svédországban, Magyarországon és Luxemburgban még rosszabb a helyzet), és 38\%-os a lemorzsolódási arány. Többek között máig sem teljesült a diákok számára a méltányosság és az egyenlő lehetőségek biztosítása. Örvendetesnek tartják 
a szerzők, hogy a bejövő és a kimenő mobilitás is folyamatosan növekszik, mégis úgy vélik, hogy az olasz felsőoktatás minden erőfeszítés dacára csak igen vitatható eredményeket ért el.

Spanyolországban az 1975-ös nagy politikai változást követően az oktatás állami irányítás alá került. A régiók ugyan idővel egyre nagyobb szerepet kaptak, de a terület az egészségüggyel és a szociális szolgáltatásokkal együtt máig az állami koordináció része. $\mathrm{Az}$ országban a felsőoktatásban végrehajtott számít az egyik legfontosabb reformnak. A tanulmány szerint az egyetemi rendszer ugyan belefogott a modernizációba, ennek hatása azonban igen korlátozott, mert a spanyolok nem voltak felkészülve a változásokra. A tudomány nyitottsága és a big data kihívásai tovább nehezítik a felsőoktatás eddig sem könnyű helyzetét.

Portugáliában a forradalom éve (1974) hozott igazi változást - minden területen. Három lépcsővel jellemzi Veiga és Magalhăes a felsőoktatási reform alakulását: „a több - jobb” (1974-1996), „a több - gond” (1997-2005), „többet, de másként" (2005 óta). Bár számos előnyös változást idéztek elő a reformok (az implementációban Portugália az egyik leghatékonyabb volt), és „Bologna vállán” sokat fejlődtek a szervezeti struktúrák, a mobilitás és az európai dimenzió nem a tervezettek szerint alakult.

Írország 1973-ban csatlakozott az Európai Unióhoz, és a lakosság 90\%-a gondolja úgy, hogy a jövőben is része kíván maradni. A „kelta tigris” az oktatásra viszonylag későn, a 60-as évek közepén kezdett koncentrálni. A felsőoktatás szinte teljesen mellözött helyzetben volt, csak a 70-es évek végén hajtottak végre bizonyos reformokat, alapítottak új felsőoktatási intézményeket, melyek később egyetemekké fejlődtek. Még a 20. század végén is befektetési stratégiai és egyetemalapú kutatási müködési elképzelések híján voltak. 1998 és 2015 között müködött a Programme for Research in Third-Level Institutions nevü projekt, amely a felsőoktatásba addig példátlan befektetést hozott. Az ugyanabban az időben alakult kutatási tanácsok is hozzájárultak ahhoz, hogy az alapkutatás nagyobb összegekhez jusson (különösen a STEM területeken). Mivel Írország kicsi és nyitott gazdasága egyértelműen függ az Európai Uniótól, a fejezet írói úgy látják, hogy a bolognai folyamat töretlenül alakítja az elkövetkező években is az ország felsőoktatási stratégiájának egy részét, különös tekintettel a Brexitre.

Angliában is csupán 30 évvel ezelött indult el a felsőoktatás reformja, és hatalmas eredményeket ért el 1990 óta, már csupán az egyetemek és a diákok számát tekintve is (az Egyesült Királyságban 1990-ben 46 egyetem müködött 350 ezer diákkal, 2017-ben már 160 egyetem 2 millió 300 ezer diákkal, és ebből Angliában: 132 intézmény 1 millió 800 ezer diákkal). 2017ben a törvény piaci alapokra helyezte a felsőoktatást. A United Kingdom Research and Innovation (UKRI) elnevezésű szervezet magába olvasztotta a korábbi kutató tanácsokat az interdiszciplináris együttmüködések fejlesztése érdekében. Megalakult a Diákhivatal (OfS), a törvény által előírt minőségért és a szabályok betartásáért felelős szervezet, amely többek között az egyetemek pénzügyi helyzetét, hatékonyságát vizsgálja. Ernyőszervezete az Oktatás Kiválósági Keretrendszer (TEF) az egyetemek oktatási tevékenységét jutalmazza arany, ezüst és bronz fokozattal.

Litvániában 1999 után a „kimenetikövetelmény-orientált menedzserizmus" irányába haladt a felsőoktatás (p. 179). Ez a helyzet olyan szempontból is érdekes, hogy jól tükrözi a térség hasonló szituációból az Unióba került országainak sajátosságát: a központilag irányított szovjet gazdaság nyugati piacgazdasággá módosulását. Bár 
Litvánia nagy múlttal rendelkezik a felsőoktatás terén a Vilnius Egyetem 1579-es alapítása óta, mégis az országon belüli történelmi és politikai hatások, a mezőgazdaság dominanciája erősen hatottak a felsőoktatás alakulására. Az egyetemi oktatás elsődleges célja a szovjet érában az volt, hogy elegendő orvost, tanárt, mérnököt képezzenek. Az oktatás állami kontroll alatt zajlott, a kutatás kikerült az egyetemekről. A függetlenség visszaszerzését követően szinte azonnal újraalapították a Vytautas Magnus Egyetemet Kaunasban. $\mathrm{A} z$ EuroFaculty programnak nagy hatása volt a balti egyetemek nyugat-európai mintára formálódásában. A $z$ alap- és mesterképzés, a minőségbiztosítási ügynökség alapítása, amely a külföldi diplomák ellenőrzését és honosítását végezte, nem a bolognai idők gyermeke (ebben Amerikából és Kanadából visszatérő litvánok játszottak szerepet), ennek ellenére a szakemberek egyetértenek abban, hogy a bolognai folyamat jelentős változásokat és sikereket hozott, és hozzájárult a szovjet felsőoktatási modelltől való elszakadáshoz.

Kováts Gergely a magyarországi processzust bemutató fejezetben azt hangsúlyozza, hogy a bolognai folyamat „választópont”, hiszen homogenizálta a felsőoktatást. Kiemeli, hogy Bologna a közép- és kelet-európai országokban mást, többet jelentett, mint egyszerüen a hat kitűzött cél elérését, „trójai faló” volt, amelynek hatására a bolognai célokon túl társadalmi reformváltozások is lezajlottak. A tanulmányból tájékozódhatunk a magyar felsőoktatás rendszerváltás utáni három legfontosabb szakaszáról, az oktatási intézmények, a szakok, a hallgatók, a tanárok számának alakulásáról, a bolognai célok magyarországi megfogalmazásáról, a különböző érdekcsoportok által képviselt álláspontokról (hogyan nehezedett a politikai vezetőkre a nemzetközi elvárások nyomása, illetve az egyetemi oktatók és egye- tem körüli közösségek miként vélekedtek a tervezett intézményi kormányzási reformmal kapcsolatban). Hiába vonta be az Oktatási Minisztérium a törvényalkotás előkészítő folyamatába a legkülönfélébb szervezetek képviselőit, „felülről lefelé” logika érvényesült a törvényalkotásban és a törvény bevezetésében.

Egyes nézetek szerint az egész bolognai folyamat mögött gazdasági okok húzódnak, hiszen szorosan kapcsolódik a Lisszaboni Stratégiához, amely a szabad munkaerő-áramlást hangsúlyozza az európai országok között. Hogyan válhat bonyodalommentessé az országok közötti vándorlás? Úgy, hogy összehasonlíthatóvá, egységesebbé, harmonizálhatóvá válik a képzés Európában.

$\mathrm{Az}$ Európai Unió kulcskompetenciái, ${ }^{1}$ melyekkel kapcsolatban a Tanács 2018 májusában egy nyilatkozatot jelentetett meg, többek között azt is kijelenti, hogy „mindenkinek joga van a minőségi és inkluzív oktatáshoz, képzéshez és az egész életen át tartó tanuláshoz olyan készségek fenntartása és megszerzése érdekében, amelyek lehetővé teszik a teljes társadalmi részvételt és a munkapiacon való sikeres átjárást" (EC 2018). Hogy ezek a célok megvalósulnak-e, hogy a globális valóság visszatükrözi-e a globális elképzeléseket, hogy az angolszász minta érintetlenül maradhat-e Anglia távozását követően, hogy lesz-e Európai Oktatási Térség 2025-re - mindezekre a kérdésekre a könyvben bemutatott magas színvonalú, komplex, átfogó vizsgálatok nyomán született válaszok korántsem maguktól értetődők, és az is lehetséges, hogy az igazi válaszadók, a programok leendő megvalósítói még éppen az európai felsőoktatás elméleti és gyakorlati tapasztalatait gyüjtik valamelyik európai egyetemen.

http://mobilitycompetences.com/wp-content/ uploads/2016/10/The-8-key-competences-ofEuropean-Union.pdf 


\section{IRODALOM}

EC (2018) Council recommendation of 22 May 2018 on key competences for lifelong learning (Text with EEA relevance) (2018/C 189/01). Official Journal of the European Union, 4. 6. 2018, C 189/1-13.

KIss Á. (1969) Müveltség és iskola. Budapest, Akadémiai Kiadó.

OECD (2018) Education at a glance 2018: OECD indicators. Paris, OECD Publishing.

A cikk a Creative Commons Attribution 4.0 International License (https://creativecommons.org/licenses/ by-nc/4.0/) feltételei szerint publikált Open Access közlemény, melynek szellemében a cikk bármilyen médiumban szabadon felhasználható, megosztható és újraközölhető, feltéve, hogy az eredeti szerző és a közlés helye, illetve a CC License linkje és az esetlegesen végrehajtott módosítások feltüntetésre kerülnek. 